\title{
Membrane Distribution of Sodium-Hydrogen and Chloride-Bicarbonate Exchangers in Crypt and Villus Cell Membranes from Rabbit lleum
}

\author{
Roy G. Knickelbein, ${ }^{\star}$ Peter S. Aronson, ${ }^{\star \ddagger}$ and John W. Dobbins* \\ Department of *Medicine and ${ }^{\ddagger}$ Physiology, Yale University School of Medicine, New Haven, Connecticut 06510
}

\begin{abstract}
Present evidence suggests that in the small intestine, villus cells are primarily absorptive and crypt cells are primarily secretory. In order to further confirm that there are differences in transport properties between villus and crypt cells, we have separated villus from crypt cells, using calcium chelations techniques, and determined the distribution of $\mathrm{Na}: \mathrm{H}$ and $\mathrm{Cl}: \mathrm{HCO}_{3}$ exchange activity on brush border membrane and basolateral membrane preparations from these two cell populations.

Separation of cells was determined utilizing alkaline phosphatase and maltase activity as a marker of villus cells and thymidine kinase activity as a marker of crypt cells. Utilizing these techniques, we were able to sequentially collect cells along the villus-crypt axis. Na-stimulated glucose and alanine uptake in brush border membrane vesicles diminished from the villus to the crypt region in the sequentially collected cells fractions, further suggesting separation of these cells.

Brush border and basolateral membranes were then prepared from cells from the villus and crypt areas, utilizing a continuous sucrose gradient. In the villus cells, $\mathrm{Na}: \mathrm{H}$ exchange activity was found associated with both the brush border and basolateral membrane, whereas, in crypt cells, $\mathrm{Na}: \mathrm{H}$ exchange activity was only found on the basolateral membrane. $\mathrm{Cl}: \mathrm{HCO}_{3}$ exchange activity was found only on the brush border membrane, in both villus and crypt cells. These studies suggest functional heterogeneity in ion transport between villus and crypt cells.
\end{abstract}

\section{Introduction}

A considerable amount of indirect evidence has accumulated suggesting that, in the intestine, villus or surface cells are the site of absorption of nutrients and electrolytes, and crypt cells are the site of secretion. Evidence indicating that villus cells are the site of absorption include the presence of a well-developed brush border and a greater concentrations of brush border hydrolytic enzymes when compared to crypt cells (1-5), the occurrence of malabsorption in diseases characterized by loss of villi, and the loss of $\mathrm{Na}$-coupled glucose and $\mathrm{Cl}$ absorption in diseases characterized by loss of villi, such as sprue and viral gastroenteritis (6-9). Evidence indicating that crypt cells are

Address correspondence and reprint requests to Dr. Dobbins, Department of Medicine, Yale University School of Medicine, P.O. Box 3333, New Haven, CT 06510.

Received for publication 8 February 1988 and in revised form 27 June 1988.

J. Clin. Invest.

(c) The American Society for Clinical Investigation, Inc.

$0021-9738 / 88 / 12 / 2158 / 06 \quad \$ 2.00$

Volume 82, December 1988, 2158-2163 the site of secretion include $(a)$ the occurrence of net fluid and electrolyte secretion in disease states characterized by the loss of villus, but not crypt cells $(9,10)$, and $(b)$ the demonstration that crypt cells, but not surface cells, secrete $\mathrm{Cl}(11-13)$.

We and others have previously demonstrated that $\mathrm{Na}: \mathrm{H}$ and $\mathrm{Cl}: \mathrm{HCO}_{3}$ exchange occurs on the brush border membrane $(B B M)^{1}$ in mammalian ileum, and probably account for the coupling of $\mathrm{Na}$ and $\mathrm{Cl}$ absorption in the ileum $(14,15)$. In these studies, no attempt was made to distinguish between crypt and villus regions.

If there are differences in transport properties between villus and crypt cells, then one might expect differences in the membrane distribution of transporters, such as the $\mathrm{Na}: \mathrm{H}$ and $\mathrm{Cl}: \mathrm{HCO}_{3}$ exchangers along the villus-crypt axis. In this study we have separated villus from crypt cells in rabbit ileum and determined the presence of $\mathrm{Na}: \mathrm{H}$ and $\mathrm{Cl}: \mathrm{HCO}_{3}$ exchange in BBM and basolateral membranes (BLM) prepared from these two cell populations.

\section{Methods}

Separation of villus and crypt cells. The sequential isolation of villus and crypt cell populations was achieved by a combination of the methods of Weiser (4) and Bjerkness and Cheng (16). Male New Zealand white rabbits weighing $2-3 \mathrm{~kg}$, fasted overnight, were anesthetized with sodium pentobarbital $(35 \mathrm{mg} / \mathrm{kg}$ ) and the abdomen was opened. The anterior (superior) mesenteric artery was cannulated, then infused for $2 \mathrm{~min}$ with $60 \mathrm{ml}$ of buffer A, consisting of (in millimolar): $96 \mathrm{NaCl}$, $27 \mathrm{Na}$ citrate, $0.8 \mathrm{KH}_{2} \mathrm{PO}_{4}, 5.6 \mathrm{Na}_{2} \mathrm{HPO}_{4}, 1.5 \mathrm{KCl}, 0.5 \mathrm{Na}$ hydroxybutyrate, 0.5 dithiothreitol, 10 glucose, 2.5 glutamine, $\mathrm{pH}$ 7.4. The anterior mesenteric vein was nicked to allow blood to clear from the ileum. The rabbit was then killed by further injection of sodium pentobarbital and only the ileum cleared of blood $\left(\sim 3^{1 / 2} \mathrm{ft}\right)$ removed. The intestine was rinsed thoroughly with buffer $\mathrm{A}$, cut into 6-in segments, everted, and incubated for $20 \mathrm{~min}$ at $37^{\circ} \mathrm{C}$ in buffer $\mathrm{A}$ gassed with $5 \%$ $\mathrm{CO}_{2}, 95 \% \mathrm{O}_{2}$. The intestine was then sequentially incubated in a series of six 200-ml plastic centrifuge bottles containing buffer $\mathrm{B}$, consisting of (in millimolar): $112 \mathrm{NaCl}, 2.4 \mathrm{~K}_{2} \mathrm{HPO}_{4}, 0.4 \mathrm{KH}_{2} \mathrm{PO}_{4}, 25 \mathrm{NaHCO}_{3}$, 1.5 EDTA, 10 glucose, 2.5 glutamine, $0.5 \mathrm{Na}$ hydroxybutyrate, 0.5 dithiothreitol, and gassed with $5 \% \mathrm{CO}_{2}, 95 \% \mathrm{O}_{2}$ at $37^{\circ} \mathrm{C}(\mathrm{pH} 7.4)$. The incubations were carried out for $10,10,10,15,15$, and $30 \mathrm{~min}$, respectively. The everted ileal segments were then placed on a $1-\mathrm{ml}$ plastic pipette and vibrated for $8 \mathrm{~min}$ at 60 cycles/s in ice-cold buffer B. Cells released into each of the eight solutions were collected by centrifuging at $100 \mathrm{~g}$ for $5 \mathrm{~min}$, and washed twice with buffer $\mathrm{B}$ (without dithiothreitol). If membrane vesicles were to be prepared from these cells, the isolation procedures were carried out immediately.

Preparation of membrane vesicles. BBM vesicles were prepared by a cation precipitation technique as previously described (14) except that isolated cells were used rather than scraped mucosa. Uptake studies were performed on the same day the vesicles were prepared. Vesicles from the villus region were enriched $10.7 \pm 3$.2-fold $(15.4 \pm 5.7$ $\Delta$ OD $\min ^{-1} \mathrm{mg}$ protein ${ }^{-1}, n=3$ ) and cells from the crypt region were

1. Abbreviations used in this paper: BBM, brush border membrane; BLM, basolateral membrane; DIDS, 4,4'-diisothiocyanatostilbene2,2'-disulfonic acid; MES, 2-( $N$-morpholino)ethanesulfonic acid; TMA, tetramethyl ammonium. 
enriched $11.6 \pm 0.7$ fold $\left(6.1 \pm 0.8 \Delta \mathrm{OD} \min ^{-1} \mathrm{mg}\right.$ protein $\left.{ }^{-1}, n=3\right)$ in maltase activity.

Simultaneous preparation of BBM and BLM was performed utilizing a continuous sucrose gradient. The isolated cells were diluted 1:1 $(w t / v o l)$ with sucrose buffer $(250 \mathrm{mM}$ sucrose, $12 \mathrm{mM}$ Tris, $16 \mathrm{mM}$ Hepes, $1 \mathrm{mM}$ EDTA, and $0.1 \mathrm{mM}$ PMSF). The tissue was homogenized 10 strokes with a Brendler-type homogenizer. This step was repeated after allowing the tissue to cool on ice for $2 \mathrm{~min}$. The homogenate was further diluted with $1.5 \mathrm{vol}$ of sucrose buffer and centrifuged at $3,000 \mathrm{~g}$ for $10 \mathrm{~min}$. The pellet was discarded and the supernate was centrifuged at $41,000 \mathrm{~g}$ for $30 \mathrm{~min}$. The supernate was discarded and the pellet was resuspended in sucrose buffer, homogenized 20 strokes, and then centrifuged at $41,000 \mathrm{~g}$ for $30 \mathrm{~min}$. The supernate was discarded and the pellet resuspended in $60 \%$ sucrose. $2 \mathrm{ml}$ of these membranes was layered at the bottom of a $28-48 \%$ continuous sucrose gradient and centrifuged at $195,700 \mathrm{~g}$ for $2 \mathrm{~h}$. 13 fractions $(\sim 0.9 \mathrm{ml}$ per fraction) were collected, diluted severalfold with sucrose buffer, and pelleted at $244,000 \mathrm{~g}$ for $40 \mathrm{~min}$. The pellets were resuspended in $30 \mathrm{ml}$ of buffer and left on ice overnight. The membranes were then pelleted as described above and resuspended in sucrose buffer and used for transport studies.

Vesicle transport studies. After a 2-h preincubation at room temperature, a $10-\mu l$ aliquot of vesicles was added to a reaction solution containing radioisotope and uptake allowed to proceed (see figure legends for composition of solutions). When $\mathrm{HCO}_{3}$ was used, all media were gassed with $95 \% \mathrm{~N}_{2}, 5 \% \mathrm{CO}_{2}$. At varying time intervals, isotope uptake was stopped with $3 \mathrm{ml}$ ice-cold stop solution consisting of 10 $\mathrm{mM}$ Tris, $16 \mathrm{mM}$ Hepes, $\mathrm{pH} 7.5$ plus the desired $\mathrm{K}$ gluconate concentration to maintain isomolarity (preincubation medium, reaction medium, and stopping solution were always kept isomotic). The stopped solution was immediately filtered on a $0.45-\mu \mathrm{m}$ Millipore filter (Millipore Corp., Bedford, MA) (HAWP) and washed twice with $3 \mathrm{ml}$ of ice-cold stopping solution. Radioactivity was determined using a beta scintillation counter. (Beckman Instruments, Inc., Fullerton, CA).

Enzyme assays. Na-K-ATPase, a basolateral membrane enzyme, was determined indirectly by measuring ouabain-sensitive $\mathrm{K}^{+}$-stimulated neutral phosphatase by a modification of the method of Murer et al. (17) as previously described (14). Maltase, a brush border enzyme, was measured using the method of Reiss and Sacktor (18). Alkaline phosphatase activity was determined using standard reagents purchased from Sigma Chemical Co., St. Louis, MO.

Thymidine incorporation into DNA was determined as an index of thymidine kinase activity, in the following manner $(19,20) .250 \mu \mathrm{Ci}$ of [methyl $-{ }^{3} \mathrm{H}$ ] thymidine was injected intravenously $2 \mathrm{~h}$ before collection of the cell fractions. A crude DNA extraction was made by homogenizing the cells and adding an equal volume of $1 \mathrm{~N}$ perchloric acid. After allowing to stand on ice $10 \mathrm{~min}$, the tissue was centrifuged $4 \mathrm{~min}$ and the supernatant discarded. The tissue was washed twice with $0.7 \mathrm{~N}$ perchloric acid before adding $1.5 \mathrm{ml}$ of $0.1 \mathrm{~N} \mathrm{NaOH}$. The tubes were incubated at $37^{\circ} \mathrm{C}$ for $2 \mathrm{~h}$ then sat overnight at $4^{\circ} \mathrm{C} .0 .5 \mathrm{ml}$ of solubilized sample was added to a glass scintillation vial with $21 \mathrm{ml}$ of scintillation fluid and radioactivity determined in a beta counter. Thymidine incorporation was expressed as counts per minute per milligram of protein for each cell fraction.

\section{Results}

Separation of villus from crypt cells. The degree of separation of villus from crypt cells was determined utilizing enzyme markers. Alkaline phosphatase and maltase were utilized as villus cell markers and thymidine kinase was utilized as a crypt cell marker $(1,3,4)$. In Fig. 1 , it can be seen that there is a progressive decrease in maltase and alkaline phosphatase activity, and a progressive increase in thymidine kinase activity in the sequentially collected cell fractions. This indicates that there is a progressive and sequential removal of enterocytes from the villus tip to the crypts as previously demonstrated by Weiser (4).

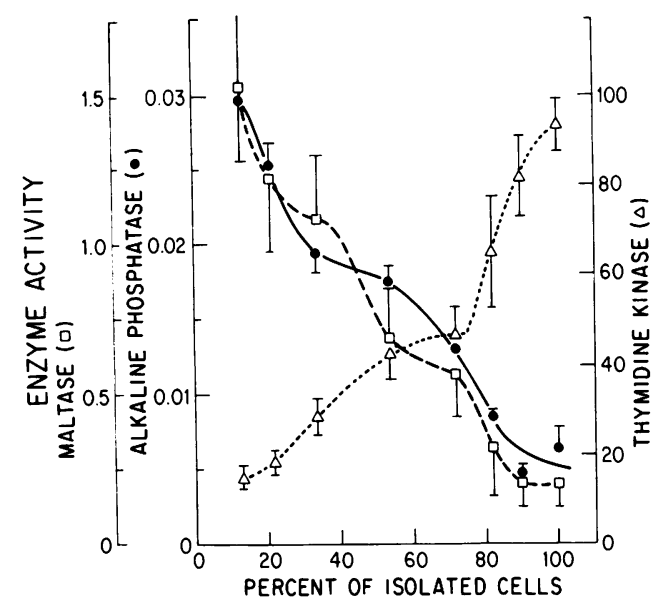

Figure 1. Enzyme activities determined in cells along the crypt-villus axis. The enzyme specific activities are shown for each cell fraction, plotted vs. the percent of total cells (determined as the sum of the protein in a given fraction plus the protein in all preceding fractions divided by the total protein). Alkaline phosphatase activity is expressed as micromoles per minute per milligram of protein and maltase activity is expressed as $\Delta$ OD per minute per milligram of protein. Thymidine kinase activity for each fraction is expressed as a percentage of the fraction with the highest activity. Results shown are means $\pm \mathrm{SE}$ for three separate cell preparations.

Localization of Na-glucose and Na-alanine cotransport. Previous studies have suggested that $\mathrm{Na}$-cotransport processes are localized to mature villus cells $(6,7,21-23)$. We, therefore, measured Na-stimulated glucose and alanine uptake in BBM vesicles prepared from the sequentially collected cell fractions. Fig. 2 illustrates that there is a progressive decline in Na-stimu-

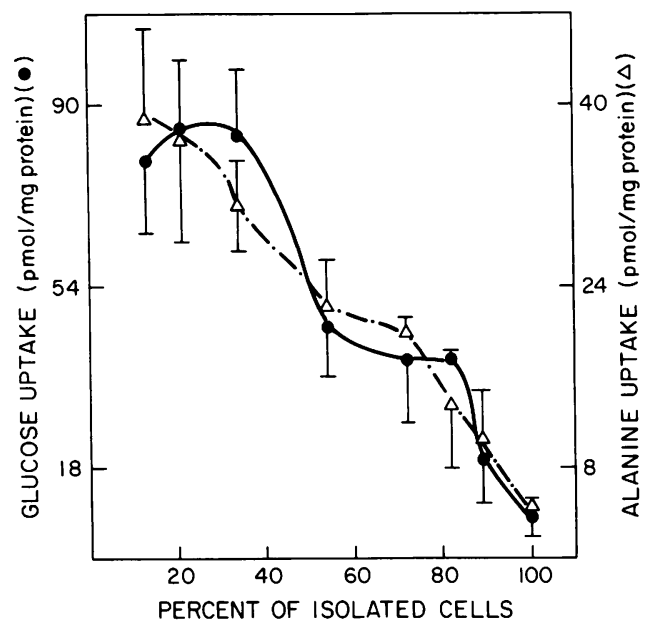

Figure 2. Sodium-stimulated uptake of glucose or alanine in brush border membrane vesicles isolated from cells along the crypt-villus axis. Brush border membranes were prepared by the cation precipitation method from each of the eight cell fractions sequentially collected along the crypt-villus axis (Fig. 1). Vesicles were preincubated with $50 \mathrm{mM}$ Tris, $96 \mathrm{mM}$ Hepes (pH 7.5), $150 \mathrm{mM}$ mannitol, and $100 \mathrm{mM}$ tetramethyl ammonium (TMA) gluconate. The uptake of $50 \mu \mathrm{M}\left[{ }^{3} \mathrm{H}\right]$ glucose or $\left[{ }^{3} \mathrm{H}\right]$ alanine was determined after dilution into a reaction medium consisting of $50 \mathrm{mM}$ Tris, $96 \mathrm{mM}$ Hepes, 150 $\mathrm{mM}$ mannitol, $20 \mathrm{mM}$ TMA gluconate, and $80 \mathrm{mM}$ of either $\mathrm{Na}$ gluconate or $\mathrm{K}$ gluconate. The results shown are the differences in 15-s uptake obtained in the presence of $\mathrm{Na}$ vs. K. Results are expressed means $\pm \mathrm{SE}$ for three preparations. 
lated glucose and amino acid uptake in the cell fractions. This result indicates a change in either $V_{\max }$ or $K_{\mathrm{m}}$ as the cells migrate up the villus and is consistent with the concept of "maturation" of absorptive functions as enterocytes migrate from crypt to villus region.

Localization of $\mathrm{Na}: \mathrm{H}$ and $\mathrm{Cl}: \mathrm{HCO}_{3}$ exchange. Fig. 3 illustrates $\mathrm{Na}: \mathrm{H}$ and $\mathrm{Cl}: \mathrm{HCO}_{3}$ exchange activity in the sequentially collected cell fractions. In this experiment $\mathrm{Na}: \mathrm{H}$ activity is pH-gradient (5.5 inside, 7.5 outside) stimulated, amiloridesensitive $\mathrm{Na}$ uptake; and $\mathrm{Cl}: \mathrm{HCO}_{3}$ exchange activity is $\mathrm{HCO}_{3}$ gradient ( $50 \mathrm{mM}$ inside, $0.286 \mathrm{mM}$ outside) stimulated, 4,4'diisothiocyanatostilbene-2,2'-disulfonic acid (DIDS)-sensitive $\mathrm{Cl}$ uptake. There is little change in $\mathrm{Cl}$ uptake in the cell fractions, whereas there is a decline in $\mathrm{Na}$ uptake, suggesting decreased $\mathrm{Na}: \mathrm{H}$ exchange as one progresses from villus to crypt area.

$\mathrm{Na}: \mathrm{H}$ exchange activity has been recently reported to be present in the BLM preparations from the rabbit ileum (24). Whether this reflects $\mathrm{Na}: \mathrm{H}$ exchange activity intrinsic to the BLM, or instead arises from BBM contamination, was not determined (25). To characterize the distribution of $\mathrm{Na}: \mathrm{H}$ exchange and $\mathrm{Cl}: \mathrm{HCO}_{3}$ exchange in these two membrane populations, we have separated BBM from BLM utilizing a contin-

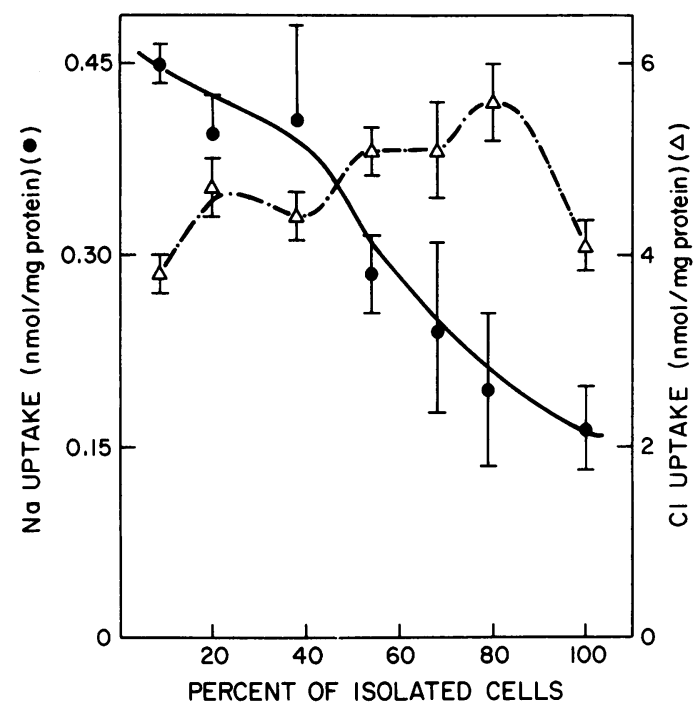

Figure 3. Na:H exchange and $\mathrm{Cl}: \mathrm{HCO}_{3}$ exchange in $\mathrm{BBM}$ vesicles isolated from cells along the crypt-villus axis. BBM were prepared by the cation precipitation method from each of the eight cell fractions sequentially collected from along the crypt-villus axis (Fig. 1). Na:H exchange was determined in vesicles preincubated with $15 \mathrm{mM}$ Tris, $20 \mathrm{mM}$ Hepes, $104 \mathrm{mM}$ 2-( $N$-morpholino)ethanesulfonic acid (MES) (pH 5.5), $150 \mathrm{mM}$ mannitol, and $100 \mathrm{mM}$ TMA gluconate. ${ }^{22} \mathrm{Na}$ uptake was determined after diluting vesicles in a reaction medium containing $58 \mathrm{mM}$ Tris, $59 \mathrm{mM}$ Hepes, $23 \mathrm{mM}$ MES (pH 7.5), 150 $\mathrm{mM}$ mannitol, $99 \mathrm{mM}$ TMA gluconate, $1 \mathrm{mM}$ Na gluconate, \pm 1 $\mathrm{mM}$ amiloride. Results shown are amiloride-sensitive $\mathrm{Na}$ uptake after $30 \mathrm{~s} . \mathrm{Cl}: \mathrm{HCO}_{3}$ exchange was determined in vesicles preincubated with $35 \mathrm{mM}$ Tris, $35 \mathrm{mM}$ Hepes, $50 \mathrm{mM}$ choline $\mathrm{HCO}_{3}$, and $100 \mathrm{mM}$ TMA gluconate while gassing with $95 \% \mathrm{~N}_{2}, 5 \% \mathrm{CO}_{2}(\mathrm{pH}$ 7.7). 30-s uptake of $5 \mathrm{mM}^{36} \mathrm{Cl}$ was determined in $95 \% \mathrm{~N}_{2}, 5 \% \mathrm{CO}_{2}$ gassed reaction medium consisting of $8 \mathrm{mM}$ Tris, $10 \mathrm{mM}$ Hepes, 52 mM MES (pH 5.5), $0.3 \mathrm{mM}$ choline $\mathrm{HCO}_{3}, 4.74 \mathrm{mM}$ choline gluconate, $145 \mathrm{mM}$ TMA gluconate, and $137.9 \mathrm{mM}$ mannitol $\pm 5 \mathrm{mM}$ DIDS. Cl: $\mathrm{HCO}_{3}$ exchange was determined as the DIDS-sensitive uptake. Results shown are means \pm SE for three preparations. Fractions 1 and 2 were combined for these experiments. uous sucrose gradient (Figs. 4 and 5). In these experiments, the first three cell fractions were combined to represent villus cells (Fig. 4) and the last two cell fractions combined to represent crypt cells (Fig. 5). Na-K-ATPase activity was utilized as a BLM marker and maltase activity as a BBM marker. The left panels in Figs. 4 and 5 represent total activity or uptake and the right panels specific activity or uptake.

In villus cells (Fig. 4), there is a single peak of $\mathrm{Cl}: \mathrm{HCO}_{3}$ activity $(\mathrm{Cl}$ uptake, panel $A$ ), which correlates with the BBM enzyme marker, maltase (panel $B$ ). In contrast, there are two peaks of $\mathrm{Na}: \mathrm{H}$ activity ( $\mathrm{Na}$ uptake), one correlating with the BLM marker, Na-K-ATPase, and one with BBM marker, maltase. Changes in specific activity (panels $C$ and $D$ ) paralleled changes in total activity. Thus, $\mathrm{Na}: \mathrm{H}$ exchange is present in both BBM and BLM of villus cells.

In crypt cells (Fig. 5), $\mathrm{Cl}: \mathrm{HCO}_{3}$ activity (panels $A$ and $C$ ) was similar to that seen in villus cells, correlating with maltase activity (panels $B$ and $D$ ). In contrast to villus cells, only one peak of $\mathrm{Na}: \mathrm{H}$ activity was seen, and this correlated with the activity of the BLM marker, Na-K-ATPase. Thus, Na:H exchange is present only in the BLM of crypt cells.

\section{Discussion}

Intestinal epithelium is characterized by continuous cell renewal. Crypt cells proliferate, move up the crypt, then along the villus until they are sloughed off into the lumen. As epithelial cells migrate up the crypt they undergo differentiation, which includes becoming tall and columnar and developing a brush border in which the microvilli are long and tightly packed (1). Mitotic activity and thymidine uptake is confined to the crypt base and mid crypt region (1-5). As the crypt cells migrate onto the villus and their brush borders become well developed, hydrolytic enzyme activity on the brush border also increases (3-5). It is these characteristics that have enabled us and previous investigators to establish techniques for the separation of crypt and villus cells.

Weiser first reported the sequential collection of cells along the villus-crypt axis, utilizing the luminal perfusion of calcium chelators (4). Utilizing this technique alone, we were unable to satisfactorily collect the crypt cells (data not shown). With intra-arterial infusion of calcium chelators alone, a technique adapted from Bjerknes and Cheng (16), crypt and villus cells sloughed simultaneously and thus could not be separated (data not shown). By combining the two techniques, however, and using only a short infusion of Ca chelators intra-arterially (see methods), we were able to achieve the sequential separation of cells along the villus-crypt axis as demonstrated in Fig. 1. These results are comparable to those previously reported by Weiser in rat intestine.

Fig. 2 illustrates that there is a decrease in Na-stimulated alanine and glucose uptake in BBM prepared along the villuscrypt axis. To our knowledge these are the first transport studies utilizing membrane vesicles prepared from cells collected along the villus-crypt axis. King et al. (23) found a similar decline in Na-stimulated alanine uptake utilizing intact tissue and an autoradiographic technique. Similar studies have not been done with glucose, however, Keljo et al. (26) have examined Na-stimulated glucose uptake in BBM in piglets with acute viral gastroenteritis. In infected animals, there is loss of villus cells and crypt hypertrophy (27). Keljo et al. (25) found diminished Na-stimulated glucose uptake in BBM prepared 

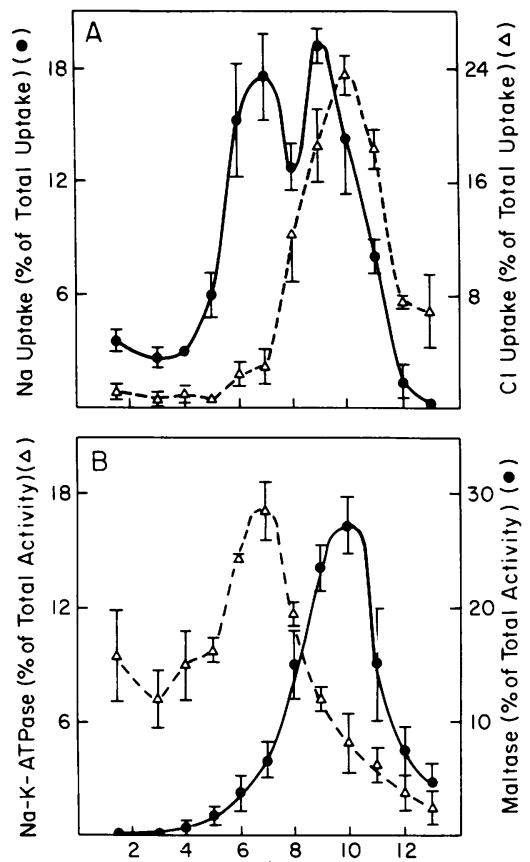
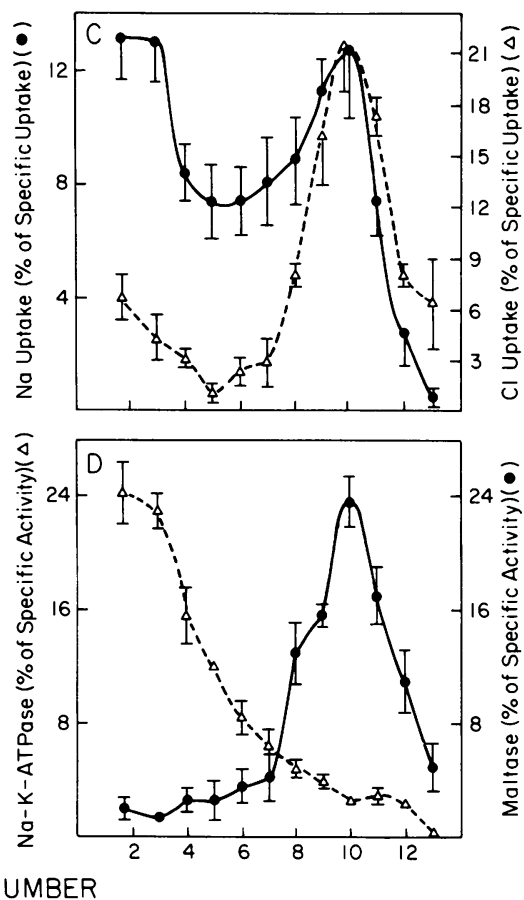

Figure 4. Transport and enzyme activity in villus cell brush border and basolateral membranes separated on a continuous sucrose gradient $(28-48 \%)$. The first three cell fractions (Fig. 1) were combined and BBM and BLM prepared simultaneously as described in the methods. The amiloride-sensitive, $\mathrm{pH}$ gradient-stimulated $\mathrm{Na}$ uptake (Na:H exchange) and DIDS-sensitive, $\mathrm{HCO}_{3}$ gradient-stimulated chloride uptake ( $\mathrm{Cl}: \mathrm{HCO}_{3}$ exchange) were determined (as described in Fig. 3) in each of the 13 fractions collected from the sucrose gradient. $\mathrm{Na} / \mathrm{K}$ ATPase activity and maltase activity were also determined. Results shown are expressed as percent total $(A, B)$ or percentage of specific activity $(C, D)$. The activity found in each fraction was determined by multiplying the specific activity (uptake per milligram protein or activity per milligram protein) by the protein in that fraction. The percent total activity was determined by dividing each fraction's activity by the total activity (sum of the 13 fractions) and multiplying by 100 . The percentage of specific activity was determined by dividing the spe-

cific activity of each fraction by the sum of all specific activities and multiplying by 100 . The specific activity of maltase in the initial homogenate was $1.4 \pm 0.6 \Delta \mathrm{OD} \mathrm{min}^{-1} \mathrm{mg}$ protein ${ }^{-1}$ and in fraction 10 was $18.7 \pm 4.6 \Delta \mathrm{OD} \mathrm{min}^{-1} \mathrm{mg}$ protein ${ }^{-1}$. The specific activity of Na/K ATPase in the homogenate was $10 \pm 1 \mathrm{nmol} \mathrm{min}{ }^{-1} \mathrm{mg}_{\text {protein }}{ }^{-1}$ and in fractions 1 and 2 was $135 \pm 35 \mathrm{nmol} \mathrm{min} \mathrm{mg}^{-1} \mathrm{mrotein}^{-1}$.

from virus-infected animals. On the basis of kinetic studies, they concluded that BBM from virus infected animals (crypt cells only) contained only a low affinity carrier of glucose whereas BBM from controls (villus and crypt cells) contained, in addition, a high-affinity carrier. They speculated that the high-affinity carrier develops during maturation of the enterocyte as it moves from crypt to villus. We did not perform kinetic studies, and thus do not know whether the decreased uptake of glucose and alanine are due to changes in $K_{\mathrm{m}}$ or $V_{\max }$.

In contrast to the diminished uptake of glucose and alanine along the villus-crypt axis, $\mathrm{Cl}: \mathrm{HCO}_{3}$ exchange was relatively constant (Fig. 3). This observation strongly suggests that this exchanger is on the BBM of both villus and crypt cells. BBM $\mathrm{Na}: \mathrm{H}$ exchange, like glucose and alanine uptake, diminished along the villus-crypt axis.
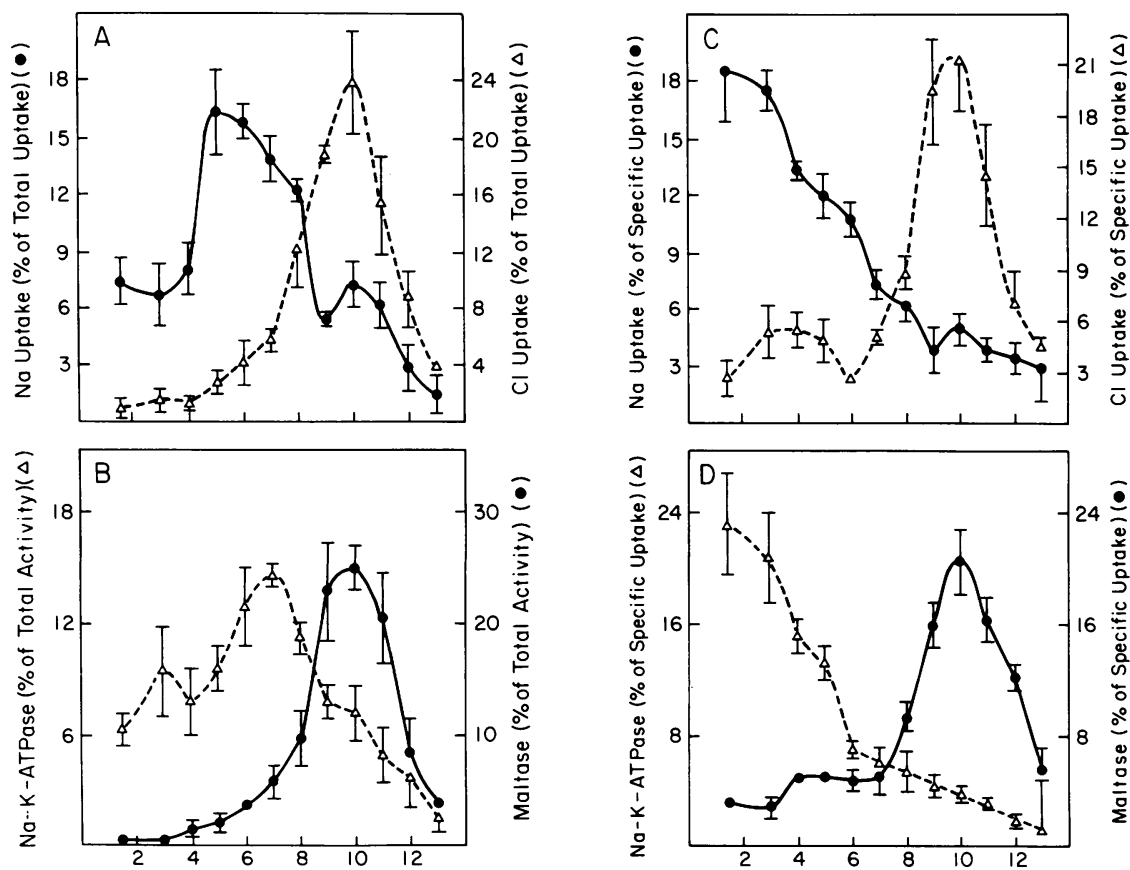

FRACTION NUMBER
Figure 5. Transport and enzyme activity in crypt cell brush border and basolateral membranes separated on a continuous sucrose gradient (28-48\%). The last two cell fractions sequentially collected (as shown in Fig. 1) were combined and BBM and BLM prepared simultaneously as described in the text. See legend to Fig. 4 for further details. The specific activity of maltase in the initial homogenate was $0.4 \pm 0.1 \Delta \mathrm{OD} \mathrm{min}^{-1} \mathrm{mg}$ protein $^{-1}$ and in fraction 10 was $10.0 \pm 2.0 \Delta$ OD min $^{-1} \mathrm{mg}_{\text {protein }}{ }^{-1}$. The specific activity of $\mathrm{Na} / \mathrm{K}$ ATPase in the homogenate was $4.4 \pm 1.6 \mathrm{nmol} \mathrm{min} \mathrm{mg}^{-1} \mathrm{mg}$ protein ${ }^{-1}$ and in fractions 1 and 2 was $72.7 \pm 7.2 \mathrm{nmol} \mathrm{min}^{-1}$ mg protein ${ }^{-1}$. 
Since $\mathrm{Na}: \mathrm{H}$ exchange activity has been recently reported to be present in the BLM preparations from rabbit small intestine (24), it was, therefore, important to determine $\mathrm{Na:H}$ exchange activity in BBM and BLM simultaneously, utilizing a continuous sucrose gradient (Figs. 4 and 5). These studies indicate that $\mathrm{Na}: \mathrm{H}$ exchange activity is present on both villus and crypt cell BLM. In contrast, $\mathrm{Na}: \mathrm{H}$ exchange activity is present on the BBM in villus cells only. The small hump of $\mathrm{Na}: \mathrm{H}$ exchange activity (Fig. 5, $A$ and $C$ ) correlating with the maltase peak in crypt cells may represent the beginning of the development of $\mathrm{Na}: \mathrm{H}$ exchange activity or slight contamination by villus cells.

The results of this study are summarized schematically in Fig. 6. Villus cells, but not crypt cells, have Na-glucose and $\mathrm{Na}$-alanine cotransporters on the BBM. Villus cells contain $\mathrm{Na}: \mathrm{H}$ and $\mathrm{Cl}: \mathrm{HCO}_{3}$ exchangers on the BBM. Thus villus cells can absorb $\mathrm{Na}$ and $\mathrm{Cl}$ in a $\mathrm{pH}$-coupled manner, as we have previously demonstrated, whereas crypt cells cannot. This observation is consistent with the general concept of the villus cell as being an absorptive cell.

A Na:H exchanger is present on the BLM of both villus and crypt cells (Fig. 6). The role of this exchanger remains to be determined. Cell $\mathrm{pH}$ regulation and volume regulation are possibilities. In many epithelia, the first step in $\mathrm{Cl}$ secretion is thought to be the coupled entry of $\mathrm{Na}$ and $\mathrm{Cl}$ or $\mathrm{Na}, \mathrm{K}$ and $\mathrm{Cl}$ across the BLM. $\mathrm{Na}$, or $\mathrm{Na}$ and $\mathrm{K}$, are then extruded back across the BLM whereas $\mathrm{Cl}$ is extruded across the BBM, resulting in electrogenic $\mathrm{Cl}$ secretion (Fig. 6; 28, 29). The possible mechanisms for the coupled entry of $\mathrm{Na}$ and $\mathrm{Cl}$ across the BLM include $\mathrm{Na}-\mathrm{Cl}$ cotransport, $\mathrm{Na}-\mathrm{K}-\mathrm{Cl}$ cotransport or $\mathrm{Na}: \mathrm{H}$ and $\mathrm{Cl}: \mathrm{HCO}_{3}$ exchange. The absence of $\mathrm{BLM} \mathrm{Cl}: \mathrm{HCO}_{3}$ activity in our study indicates that the coupled entry of $\mathrm{Na}$ and $\mathrm{Cl}$ across the BLM in rabbit ileum is unlikely to occur by dual exchange.

The crypt cell contains a $\mathrm{Na}: \mathrm{H}$ exchanger on the BLM and a $\mathrm{Cl}: \mathrm{HCO}_{3}$ exchanger on the $\mathrm{BBM}$ (Fig. 6). This configuration of these transporters suggest that the crypt cell may function as a $\mathrm{HCO}_{3}$ secreting cell. Smith et al. have reported that in vitro rabbit ileum secretes alkali into the luminal solution and acid into the serosal solution (30). Our results suggest that the crypt cell may be responsible for the observations made by Smith et al. (30), although the villus cell could also secrete bicarbonate (Fig. 6).

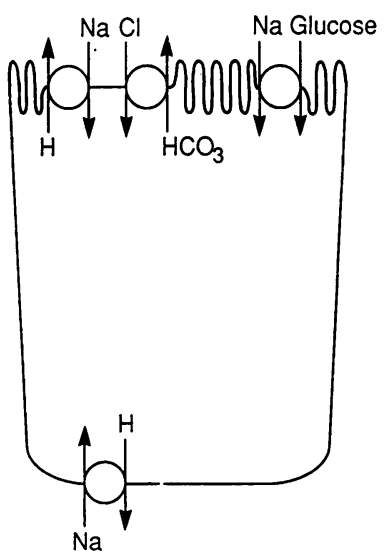

VILLUS

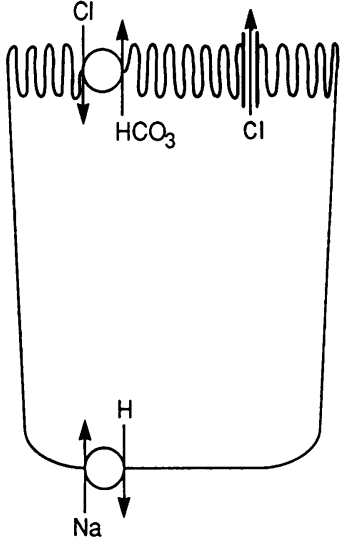

CRYPT
Figure 6. Transport pathways demonstrated in this study.
$\mathrm{HCO}_{3}$ secretion by the ileum may be an important component of many diarrhea diseases. Although current concepts of secretogogue action emphasize $\mathrm{Cl}$ secretion (see above and Fig. 6 ), studies in animals and patients with cholera have found high $\mathrm{HCO}_{3}$ content in ileal secretions and diarrheal fluid (31-33). In this context, it may be noted that $\mathrm{HCO}_{3}$ secretion via luminal membrane $\mathrm{Cl}: \mathrm{HCO}_{3}$ exchange would be enhanced by secretagogues that activate luminal membrane $\mathrm{Cl}$ channels (Fig. 6), since this would permit recycling of $\mathrm{Cl}$ across the luminal membrane.

\section{Acknowledgments}

This work was supported by grants DK-17433, DK-31969, and DK-33793 from the National Institutes of Health.

\section{References}

1. Cheng, H., and C. P. LeBlond. 1974. Origin, differentiation and renewal of the four main epithelial cell types in the mouse small intestine. Am. J. Anat. 141:461-480.

2. Alpers, D. H. 1977. Protein turnover in intestinal mucosal villus and crypt brush border membranes. Biochem. Biophys. Res. Commun. 75:130-135.

3. Nordstrom, C., A. Dahlquist, and L. Jasefsson. 1968. Quantitative determination of enzymes in different parts of the villi and crypts of rat small intestine. Comparison of alkaline phosphatase, disaccharidases, and dipeptidases. J. Histochem. Cytochem. 15:713-721.

4. Weiser, M. M. 1973. Intestinal epithelial cell surface membrane glycoprotein synthesis. I. An indicator of cellular differentiation. $J$. Biol. Chem. 248:2536-2541.

5. Miura, S., I. Song, A. Morita, R. H. Erickson, and Y. S. Kim. 1983. Distribution and biosynthesis of aminopeptidase $\mathrm{N}$ and dipeptidyl aminopeptidase IV in rat small intestine. Biochim. Biophys. Acta. 761:66-75.

6. Butler, D. G., D. G. Gall, M. H. Kelly, and J. R. Hamilton. 1974. Transmissible gastroenteritis: mechanisms responsible for diarrhea in an acute viral enteritis in piglets. J. Clin. Invest. 53:1335-1342.

7. Kerzner, B., M. H. Kelly, D. G. Gall, D. G. Butler, and J. R. Hamilton. 1977. Transmissible gastroenteritis: sodium transport and the intestinal epithelium during the course of viral enteritis. Gastroenterology. 72:457-461.

8. Roggin, G. M., J. G. Banwell, J. H. Yardley, and T. R. Hendrix. 1972. Unimpaired response of rabbit jejunum to cholera toxin after selective damage to villus epithelium. Gastroenterology. 63:981-989.

9. MacLeod, R. J., and J. R. Hamilton. 1987. Absence of a cAMPmediated antiabsorptive effect in an undifferentiated jejunal epithelium. Am. J. Physiol. 252:G776-G782.

10. Fordtran, J. S., F. C. Rector, T. W. Locklear, and M. F. Ewton. 1967. Water and solute movement in the small intestine of patients with sprue. J. Clin. Invest. 46:287-298.

11. Welsh, M. J., P. L. Smith, M. Fromm, and R. A. Frizzell. 1982. Crypts are the site of intestinal fluid and electrolyte secretion. Science (Wash. DC). 218:1219-1221.

12. Horvath, P. J., P. C. Ferriola, M. M. Weiser, and M. E. Duffey. 1986. Localization of chloride secretion in rabbit colon: inhibition by anthracene-9-carboxylic acid. Am. J. Physiol. 250:G185-G190.

13. Hallback, D., M. Jodal, A. Sjoquist, and O. Lundgren. 1982. Evidence for cholera secretion emanating from the crypts. Gastroenterology. 83:1051-1056.

14. Knickelbein, R. G., P. S. Aronson, W. Atherton, and J. W. Dobbins. 1983. Sodium and chloride transport across rabbit ileal brush border. I. Evidence for Na-H exchange. Am. J. Physiol. 245:G504G510.

15. Knickelbein, R. G., P. S. Aronson, J. Seifter, C. M. Schron, and J. W. Dobbins. 1985. Sodium and chloride transport across rabbit ileal 
brush border. II. Evidence for $\mathrm{Cl}-\mathrm{HCO}$ exchange and mechanism of coupling. Am. J. Physiol. 249:G236-G245.

16. Bjerknes, M., and H. Cheng. 1981. Methods for the isolation of intact epithelium from the mouse intestine. Anat. Rec. 199:565-574.

17. Murer, H., E. Ammann, J. Biber, and U. Hopfer. 1976. The surface membrane of the small intestinal epithelial cell. I. Localization of adenyl cyclase. Biochim. Biophys. Acta. 433:509-519.

18. Reiss, U., and B. Sacktor. 1981. Kidney brush border membrane maltase: Purification and properties. Arch. Biochem. Biophys. 209:342-348.

19. Hoffman, A. G. D., and A. Kukis. 1979. Improved isolation of villus and crypt cells from rat small intestinal mucosa. Can J. Physiol. Pharmacol. 57:832-842.

20. Hartman, F., R. Owen, and D. M. Bissell. 1982. Characterization of isolated epithelial cells from rat small intestine. Am. J. Physiol. 242:G147-G155.

21. Kinter, W. B., and T. H. Wilson. 1965. Autoradiographic study of sugar and amino acid absorption by everted sacs of hamster intestine. J. Cell Biol. 25:19-39.

22. Paterson, J. Y. F., F. V. Sepulveda, and M. W. Smith. 1980. A sodium-independent low affinity transport system for neutral amino acids in rabbit ileal mucosa. J. Physiol. (Lond.). 298:333-346.

23. King, I. S., F. V. Sepulveda, and M. W. Smith. 1981. Cellular distribution of neutral and basic amino acid transport systems in rabbit ileal mucosa. J. Physiol. (Lond.). 319:355-368.

24. Barros, F., P. Dominquez, G. Velasco, and P. S. Lazo. 1986. $\mathrm{Na} / \mathrm{H}$ exchange is present in basolateral membranes from rabbit small intestine. Biochem. Biophys. Res. Commun. 134:827-834.

25. Schron, C. M., R. G. Knickelbein, P. S. Aronson, and J. W. Dobbins. 1987. Evidence for carrier-mediated Cl-SO exchange in rab- bit ileal basolateral membrane vesicles. Am. J. Physiol. 253:G404G410.

26. Keljo, D. J., R. J. MacLeod, M. H. Perdue, D. G. Butler, and J. R. Hamilton. 1985. D-glucose transport in piglet jejunal brush border membranes: insights from a disease model. Am. J. Physiol. 249:G751-G760.

27. Shepherd, R. W., D. G. Butler, E. Cutz, D. G. Gall, and J. R. Hamilton. 1979. The mucosal lesion in viral enteritis. Extent and dynamics of the epithelial response to virus invasion in transmissible gastroenteritis of piglets. Gastroenterology. 76:770-777.

28. Heintze, K., C. Stewart, and R. Frizzell. 1983. Sodium-dependent chloride secretion across rabbit descending colon. Am. J. Physiol. 244:G357-G365.

29. Donowitz, M., and M. J. Welsh. 1987. Regulation of mammalian small intestinal electrolyte secretion. In Physiology of the Gastrointestinal Tract. 2nd edition. L. R. Johnson, editor. Raven Press, New York. 1351-1388.

30. Smith, P. L., M. A. Cascairo, and S. K. Sullivan. 1985. Sodium dependence of luminal alkalinization by rabbit ileal mucosa. $A m$. $J$. Physiol. 249:G358-G368.

31. Hubel, K. A. 1974. The mechanism of bicarbonate secretion in rabbit ileum exposed to choleragen. J. Clin. Invest. 53:964-970.

32. Moore, W. L., F. A. Bieberdorf, S. G. Morawski, R. A. Finkelstein, and J. S. Fordtran. 1971. Ion transport during cholera-induced ileal secretion in the dog. J. Clin. Invest. 50:312-318.

33. Banwell, J. G., N. G. Pierce, R. C. Mitra, K. L. Brigham, G. J. Caranasos, R. I. Keimowitz, D. S. Fedson, J. Thomas, S. L. Gorbach, B. Sack, and A. Mondal. 1970. Intestinal fluid and electrolyte transport in human colon. J. Clin. Invest. 49:183-195. 